ORNL-2872

UC.70-Radioactive Waste

TID.4500 (15th ed.)

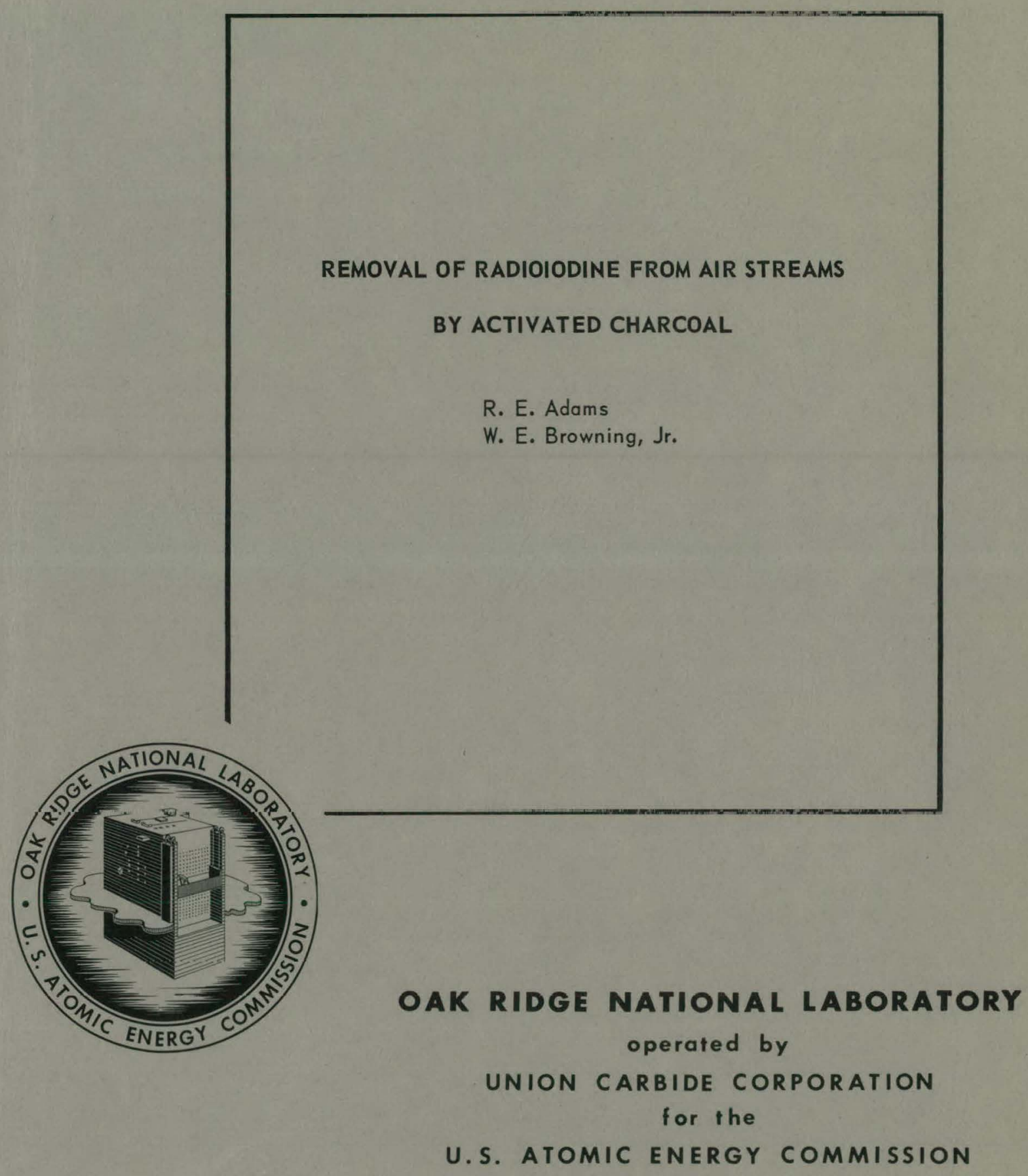




\section{DISCLAIMER}

This report was prepared as an account of work sponsored by an agency of the United States Government. Neither the United States Government nor any agency Thereof, nor any of their employees, makes any warranty, express or implied, or assumes any legal liability or responsibility for the accuracy, completeness, or usefulness of any information, apparatus, product, or process disclosed, or represents that its use would not infringe privately owned rights. Reference herein to any specific commercial product, process, or service by trade name, trademark, manufacturer, or otherwise does not necessarily constitute or imply its endorsement, recommendation, or favoring by the United States Government or any agency thereof. The views and opinions of authors expressed herein do not necessarily state or reflect those of the United States Government or any agency thereof. 


\section{DISCLAIMER}

Portions of this document may be illegible in electronic image products. Images are produced from the best available original document. 


\section{Printed in USA. Price $\$ 0.50$. Available from the \\ Office of Technical Services \\ Department of Commerce \\ Washington 25, D.C.}

\section{LEGAL NOTICE}

This report was prepared as an account of Government spansored work. Neither the United States, nor the Commission, nor any person acting on behalf of the Commission:

A. Makes any warranty or representation, expressed or implied, with respect to the accuracy, completeness, or usefulness of the information contained in this report, or that the use of any information, opparatus, method, or process diselosed in this report may not infringe privately owned rights; or

B. Assumes any liabilities with respect to the use of, or for damages resulting from the use of any information, apparatus, method, or process disclosed in this report.

As used in the above, "person acting on behalf of the Commission" includes any employee or contractor of the Commission, or employee of such contractor, to the extent that such employee or contractor of the Commission, or employee of such contractor prepares, disseminates, or provides access to, any information pursuant to his employment or contract with the Commission, or his employment with such contractor. 
ORNL-2872

UC-70-Radioactive Waste TID-4500 (15th ed.)

Contract No. W-7405-eng-26

REACTOR CHEMISTRY DIVISION

\section{REMOVAL OF RADIOIODINE FROM AIR STREAMS BY ACTIVATED CHARCOAL}

R. E. Adams

W. E. Browning, Jr.

DATE ISSUED 


\title{
REMOVAL OF RADIOIODINE FROM AIR STREAMS BY ACTIVATED CHARCOAL
}

\author{
R. E. Adams
}

W. E. Browning, Jr.

\begin{abstract}
Contamination of the atmosphere by radioactive isotopes of iodine constitutes a serious biological hazard and, for this reason, provisions should be made at reactors to prevent such releoses in the event of an accident. The efficiency of activated chorcoal for adsorption of iodine vapor from air streams was measured by using a rodioactive tracer method, and efficiencies of 99.6 to $99.999+\%$ were obtained for various conditions. Comparative tests were run with silverplated copper ribbon. A criterion for selecting an iodine removal material was developed based on efficiency and resistance to air flow. The iodine vapor adsorption efficiency of a commercial charcoal filter was measured. Vorious moterials were considered for possible application in the emergency exhuust system of the building housing the 5-Mw swimming pool reactor at the Puerto Rico Nuclear Center. Based upon its high adsorption efficiency and retention properties, it is proposed that activated charcool be utilized for iodine vapor adsarption,
\end{abstract}

\section{INTRODUCTION}

Radioactive isotopes of iodine, by-products of fissioning $U^{235}$, present a somewhat unique biological hazard because inhaled and ingested iodine is concentrated in the thyroid gland. For this reason the release of radioactive iodine vapor into the atmosphere should be avoided. Very large quantities of iodine isotopes are contained in the fuel of operating nuclear reactors. As an example, a reactor operating for 39 days at an average flux of $10^{14}$ neutrons. $\mathrm{cm}^{-2} \cdot \mathrm{sec}^{-1}$ will contain approximately $2.5 \times 10^{5}$ curies of mixed isotopes of iodine per megawatt of power level. A reactor accident, such as core meltdown, could release a large fraction of this iodine. Provisions must be made to prevent this iodine vapor from entering the atmosphere and contaminating the surrounding populated areas.

This study was conducted to determine a feasible method for iodine vapor adsorption to be used in the emergency ventilation system of the building housing the 5-Mw swimming pool reactor at the Puerto Rico Nuclear Center (PRNC). In the event of a reactor accident, building air will be diverted from the normal exhaust system and passed through the emergency exhaust system which will contain provisions for the removal of particulate matter in addition to iodine vapor. This system must be capable of going into immediate operation without supervision and must continue to operate remotely until the contaminated building air has been processed and reactor personnel are able to re-enter the building. For contamination control to be successful, the system must remove radioiodine vapor and particulate matter from the exhaust air with high efficiency and contain this material for a length of time greater than that required to completely change the building atmosphere.

\section{METHODS FOR ADSORPTION OF IODINE VAPOR}

Various methods have been reported for removal of iodine vapor from air streams. These methods may be grouped into several categories: gas scrubbers utilizing liquid absorbents (9, 14, 16); systems based upon the reaction between iodine vapor and silver nitrate at high temperatures $(3,11,12)$; and systems using solid adsorbents at room temperature $(1,4,7,15,17)$.

The mode of emergency operation in the event of a reactor accident places certain restrictions on the method to be utilized for iodine vapor adsorption. The necessity of a high operating temperature $\left(200^{\circ} \mathrm{C}\right)$ precludes the use of a silveriodine reactor, and the mechanical problems associated with handling and maintaining large volumes of a liquid absorbent in a gas scrubber limit its application in this case. A system employing a solid adsorbent appears to be more easily adapted to the requirements of the PRNC exhaust system. 
A survey of the literature reveals that many solid materials have been studied for possible use as iodine adsorbents. Materials such as zinc granules, potassium hydroxide pellets, tin ribbon, silver-plated copper ribbon, activated alumina, porous glass spheres, activated charcoal, copper ribbon, and slag wool fibers coated with potassium oxide, silver nitrate, cadmium, cadmium-antimony, or silver have been tested for iodine vapor adsorption by the Harvard University Air Cleaning Laboratory (15). Other materials reported in the literature are Linde molecular sieves, silica gel, calcium hydroxide, and soda lime.

\section{EXPERIMENTAL}

A laboratory study of the more promising materials was conducted utilizing the system diagramed in Fig. 1. Wherever possible, the system was constructed of glass to minimize adsorption of the iodine vapor by the walls. A typical experiment involved the following operations. Elemental iodine crystals $\left(1^{127}\right.$ containing radioactive $1^{131}$ ) were contained in the U-tube, and a portion of the air supply was routed through the U-tube to sweep iodine vapor into the main air stream. The time required for introduction of all the iodine vapor into the adsorber column was approximately $15 \mathrm{~min}$, and the average iodine concentration during this time was $0.18 \mathrm{mg}$ of $1^{127}$ and $54 \mu \mathrm{c}$ of $1^{131}$ per cubic foot of air.
Air flow through the system was then continued for $24 \mathrm{hr}$. lodine vapor escaping from the adsorber column was collected downstream by the combination of a plug of carbon wool fibers, ' a CWS-6 absolute filter, and an electrostatic precipitator. After completion of the 24-hr cycle, the apparatus was disassembled and the distribution of iodine radioactivity in the adsorber column was determined by scanning with a sodium iodide scintillation crystal viewing through a small slit in a lead shield. The over-all efficiency of the system was then determined by radiochemical assay of the entire system from point $A$ to point $B$ in Fig. 1. By comparing the amount of iodine residing in the adsorber column with the amount found in the total system, an adsorption efficiency was determined. It was realized that the accuracy of this method for determining iodine adsorption efficiency depends upon the premises that all iodine passing through the adsorber was collected and that none was allowed to escape. All efforts to detect iodine activity in the effluent air were unsuccessful. In calculating the efficiency, all downstream samples (i.e., CWS-6 filter paper, aluminum liner from electrostatic precipitator, etc.) in which radioiodine could not be detected were assumed to contain an amount of $1^{131}$ equal to the

\footnotetext{
'Available from Bornebey-Cheney Co., Columbus, Ohio.
}

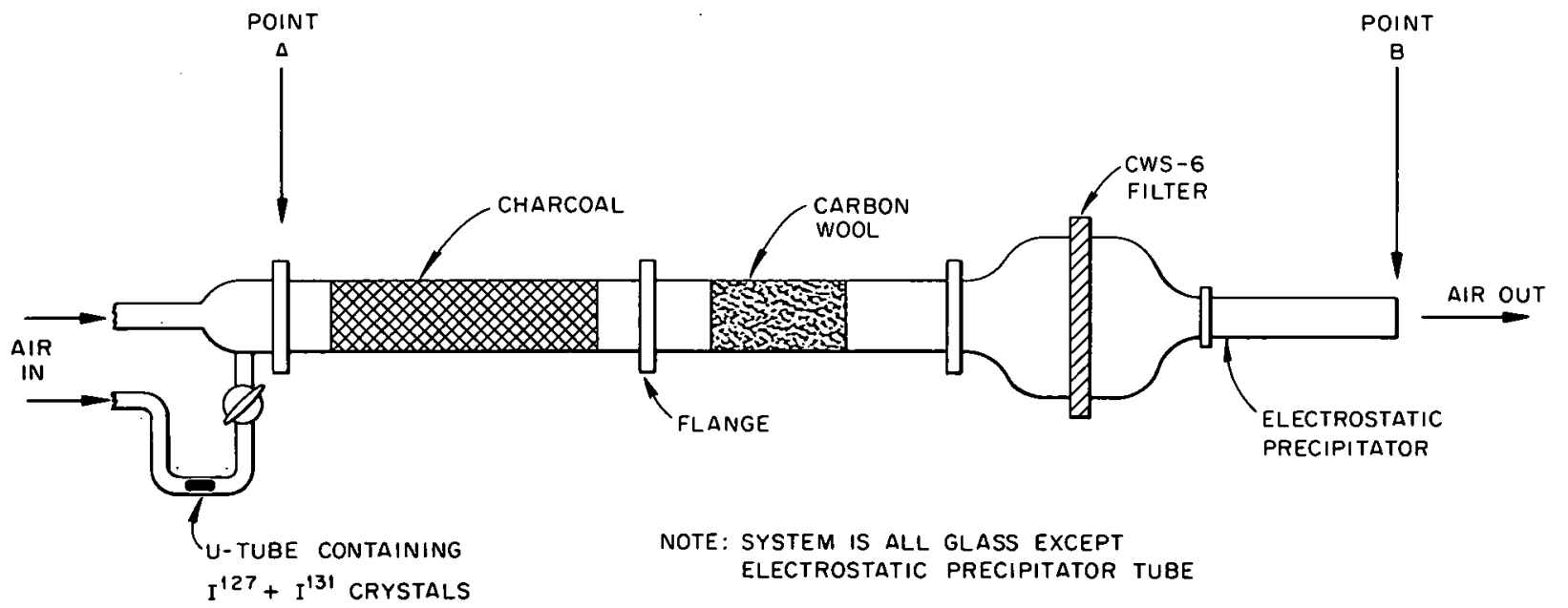

Fig. 1. Experimental System. 
limit of detection of the radiochemical method of assay. Therefore, the iodine adsorption efficiency calculated is less than the true efficiency and represents a lower limit.

The iodine tracer was prepared by adding the appropriate amount of $1^{127}$ as $\mathrm{Nal}$ to a basic sodium sulfite solution of $1^{131}$. The iodine was precipitated as palladium iodide, recovered, and dried under vacuum. To recover the tagged iodine, the dry precipitate was decomposed by heating in vacuum, and the liberated iodine vapor was collected in a U-tube cooled by liquid nitrogen. This U-tube then served as the iodine container for the experimental system.

\section{Activated Charcoal}

The major portion of this study was centered on charcoal since this material has been shown to have a very high efficiency for iodine vapor odsorption under various conditions. Parameters selected for examination were limited to those of interest in the PRNC application.

For proper design of un iodine adsorber the effect of air velocity and adsorbent particle size on the adsorption process must be known. The effect of superficial air velocity (volumetric air. flow divided by cross-sectional areo of adsorbent container) on iodine adsorption was studied at velocities of 82,170 , and $275 \mathrm{fpm}$ through adsorbers containing 6-8 mesh charcoal. Very little difference was observed. The depth of penetration into the charcoal mass and the over-all efficiency of the system were almost equal for the three air velocities. The size of the charcoal particles does affect the adsorption efficiency. Study of 2-4, 4-6, and 6-8 mesh charcoal (Columbia SXC) at a superficial air velocity of $170 \mathrm{fpm}$ yielded efficiencies of 99.63, 99.89, and $99.99+\%$, respectively. A typical iodine distribution for an adsorber 8 in. deep, containing 6-8 mesh Columbia SXC charcoal, and operated at a linear air velocity of $170 \mathrm{fpm}$ is given in Fig. 2 . For optimum performance an iodine adsorber should contain charcoal of particle size 6-8 mesh, or smaller, and even though little effect of air velocity was noted over the range studied, the air velocity should be kept low because of pressure drop and prevention of mechanical damage to the system.

Early in the study it was observed that dust particles in the air sweep might be responsible for transpert of iodine through an adsorber: iodine

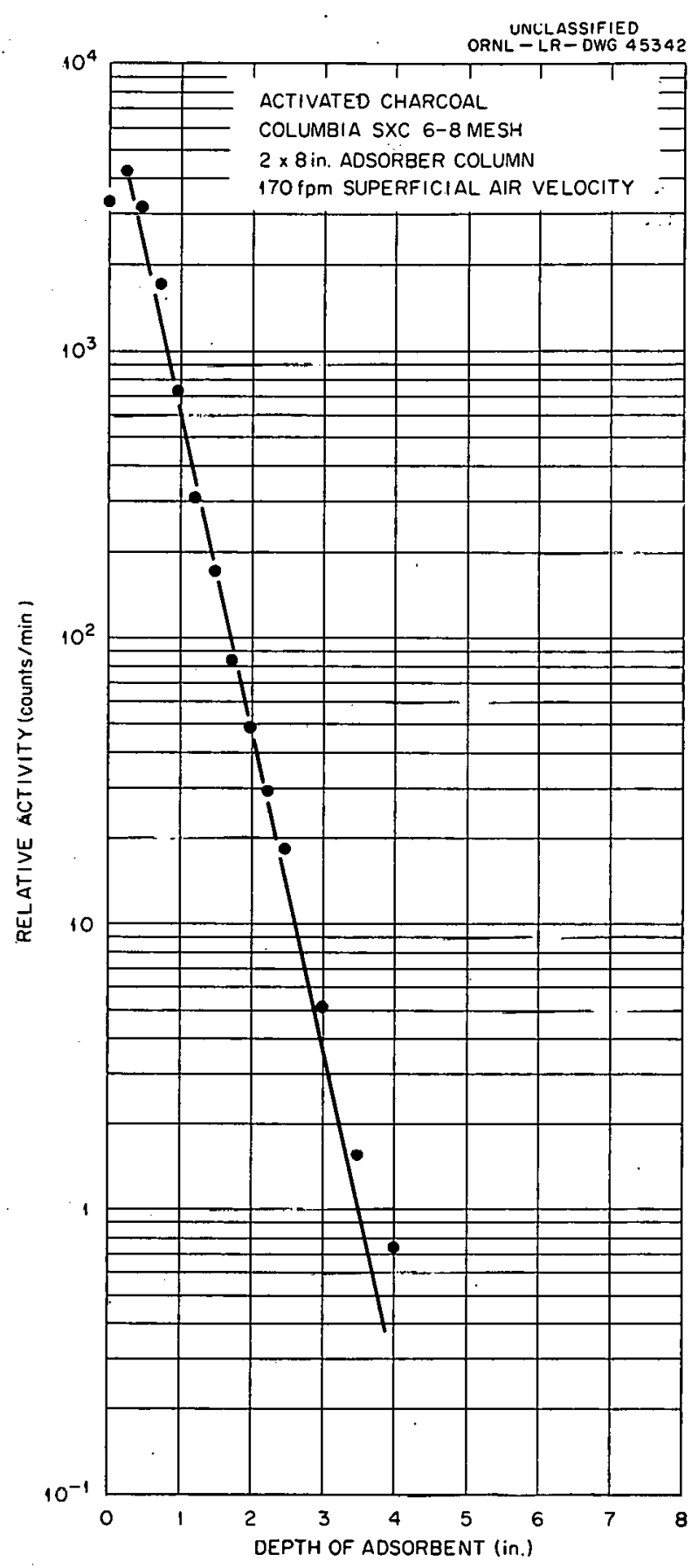

Fig. 2. Distribution of $1^{131}$ Radioactivity in Charcoal Column.

adsorbed on a particle of dust would not be available for reaction at the charcoal surface. In addition, fine particles of charcoal containing iodine might be carried from the adsorber by the air sweep. For these reasons the absolute filter (CWS-6) and the electrostatic precipitator were 
included in the experimental system in addition to the carbon wool. In one run, the CWS-6 filter was placed immediately downstream from the charcoal mass, and particularly "dusty" charcoal was used. A significant amount of dust and iodine activity. was found on the filter, and a detectable trace was found on the inner surface of the electrostatic precipitator. In all later runs the dust was removed from the charcoal before iodine injection by introducing air at a flow rate greater than that to be used in the experiment, and the dust problem was greatly reduced.

In. the PRNC application, the adsorber will be required to process contaminated air laden with moisture resulting from vaporized pool water. Possible interference by moisture contained in the air and adsorbed on the charcoal with iodine adsorption was investigated. Identical adsorbers were constructed and tested, one with dry air and the other with moist air at $82 \%$ relative humidity. The charcoal used in the wet test was exposed to moist air flow until an equilibrium quantity of moisture was contained by the charcoal, prior to the introduction of the iodine vapor. No significant effect was noted, as evidenced by an efficiency of 99.9956 and $99.9936 \%$ for the dry and wet test, respectively.

Most of the tests were operated for a 24-hr period, and during this time no downstream transport of iodine could be detected; the major portion of the iodine was concentrated at the inlet of the adsorber. One test was operated for $70 \mathrm{hr}$ after injection of the iodine, and no movement could be detected. Once adsorption takes place, the iodine is firmly held on the charcoal surface. In one reported study (7), the flow rate was increased by a factor of 20 and the temperature increased from $25^{\circ} \mathrm{C}$ to $80^{\circ} \mathrm{C}$, but the attempt to cause iodine movement after adsorption had occurred was un successful.

All tests were made at room temperature, since increased temperature had not been noted by other workers to decrease iodine adsorption efficiency. In one case, charcoal at a temperature in excess of $100^{\circ} \mathrm{C}$ in helium was successfully applied for iodine vapor adsorption (6). To prevent excessive oxidation of charcoal by air, the temperature should not be allowed to exceed $100^{\circ} \mathrm{C}$ for long periods of time.

The iodine adsorption system at PRNC will not be exposed to air flow until called upon to process building air in the event of a reactor emergency. Charcoal would not be expected to lose iodine adsorption efficiency upon exposure to air; however, to check this point, one test was made on charcoal that had been exposed to the laboratory atmosphere for several weeks and then exposed to air flow for $350 \mathrm{hr}$ prior to iodine vapor injection. An efficiency of $99.99+\%$ was obtained, and no detectable effect on iodine vapor adsorption was noted.

\section{Silver-Plated Copper Ribbon}

A large part of the work on iodine vapor adsorption at the Harvard University Air Cleaning Laboratory has been centered on silver-plated copper ribbon ${ }^{2}$ (15). Experiments have been conducted with air sweep at velocities ranging from 60 to $343 \mathrm{fpm}$, with iodine concentrations ranging from $10^{-3}$ to $30 \mathrm{mg} / \mathrm{ft}^{3}$, and at temperatures ranging from 25 to $300^{\circ} \mathrm{C}$. It was shown that iodine retention by 25 - by 2 -mil silver-plated copper ribbon at room temperature ranged up to $99 \%$ and that at $300^{\circ} \mathrm{C}$ the efficiency increased to approximately $99.9 \%$. Once the ribbon was exposed to high temperature, the efficiency dropped to $31 \%$ upon cooling to room temperature. lodine collection efficiency was also noted to be concentration dependent. The efficiency for $25-$ by 2 -mil ribbon, at a packing density of $33 \mathrm{lb} / \mathrm{ft}^{3}$, was estimated to be $90 \%$ for an iodine concentration of $1 \times 10^{-3} \mathrm{mg} / \mathrm{ft}^{3}$. The efficiency can be increased to approximately $98 \%$, however, if the ribbon dimensions are decreased to 3 by 2 mils and the packing density increased to $71 \mathrm{lb} / \mathrm{ft}^{3}$.

Three tests were made in this study by employing silver-plated copper ribbon as the adsorbent. The ribbon was 25 mils wide by 2 mils thick, woven into a mesh configuration, and coated with silver equal to $5 \%$ by weight. The runs were conducted at a face velocity of $170 \mathrm{fpm}$ and with iodine concentrations of $0.18 \mathrm{mg}$ of $\mathrm{I}^{127}$ and $54 \mu \mathrm{c}$ of $\mathrm{I}^{13.1}$ per cubic foot of air. In the first test, the air supply was filtered through a compressed air filter ("Fulflo") which had been used in the charcoal study. The adsorber contained eight ribbon pads compressed to a packing density of $25 \mathrm{lb} / \mathrm{ft}^{3}$. The iodine adsorption efficiency of the system was $92 \%$, with an iodine

\footnotetext{
${ }^{2}$ Available from Metal Textile Co., Roselle, N. J.
} 
distribution in the adsorber as shown in Fig. 3. A break is noted in the distribution curve at a depth of approximately 4 in., indicating that the efficiency beyond this depth is much lower than at the entrance. This effect has also been noted in the work at Harvard. The other two tests were run under the same conditions as before except that a CWS-6 filter was added at the air supply. The adsorption efficiency was increased to 98 and $99 \%$, indicating that particulate matter in the air supply

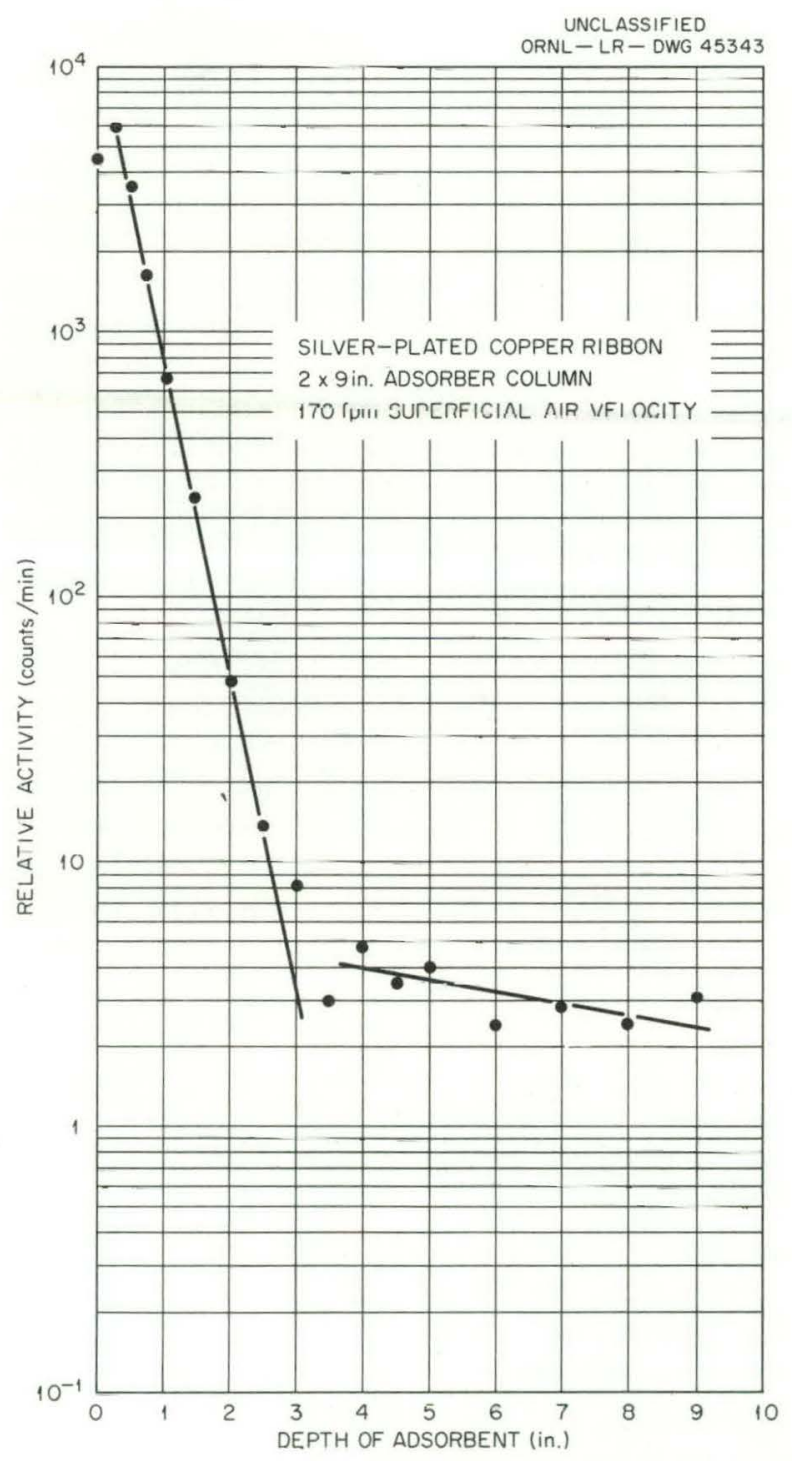

Fig. 3. Distribution of $1^{131}$ Radioactivity in SilverPlated Copper Ribbon Column. may be responsible for the transport of iodine through the silver-copper ribbon.

\section{Copper Ribbon}

One test employing new copper ribbon was made under conditions similar to those of the silvercopper tests. An iodine efficiency of $98.5 \%$ was obtained with a distribution as shown in Fig. 4. Tests at Harvard indicate that copper ribbon and silver-copper ribbon have comparable iodine

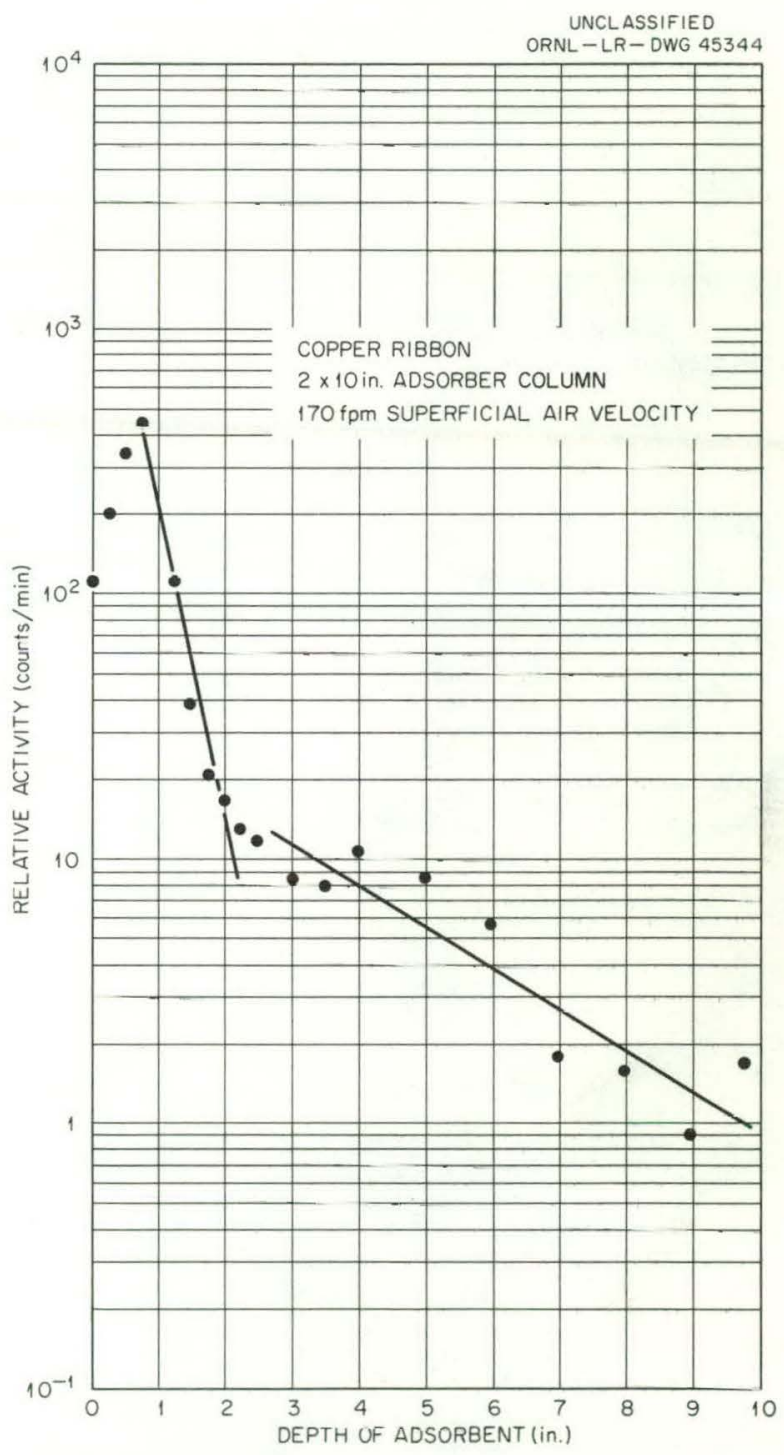

Fig. 4. Distribution of $1^{131}$ Radioactivity in Copper Ribbon Column. 
collection properties at room temperature. At elevated temperatures $\left(300^{\circ} \mathrm{C}\right)$ the copper ribbon failed after $25 \mathrm{hr}$, while the silver-copper ribbon showed no indication of reduced efficiency after $100 \mathrm{hr}$ of hot operation (15).

\section{COMPARISON OF ACTIVATED CHARCOAL AND SILVER-PLATED COPPER RIBBON}

The choice of using activated charcoal or silvercopper ribbon for iodine adsorption will depend upon the application. Each material is subject to shortcomings under various conditions.

Activated charcoal is a more efficient adsorbent, but the pressure drop through the charcoal mass is significant in some applications. Silver-copper ribbon, while being somewhat less efficient, exhibits an almost insignificant pressure drop. Figure 5 displays pressure drop as a function of superficial air velocity for several mesh sizes of charcoal and for silver-copper ribbon at a packing density of $27 \mathrm{lb} / \mathrm{ft}^{3}$.

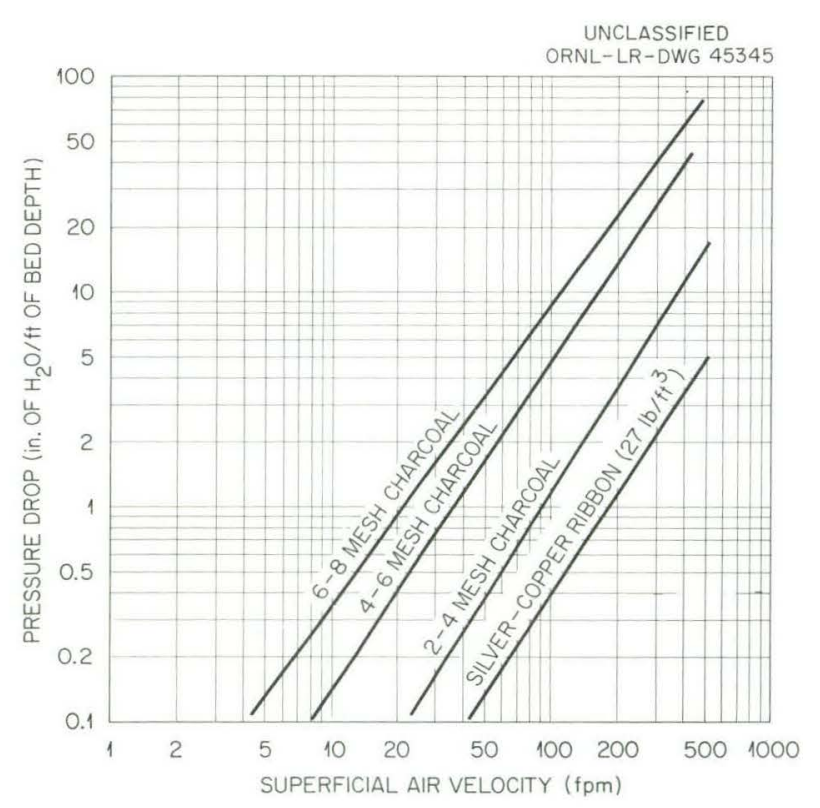

Fig. 5. Pressure Drop vs Superficial Air Velocity.

Upon comparison of the distribution curves of iodine adsorbed by charcoal and silver-copper ribbon a distinct difference is noted. The iodine distribution line for charcoal does not "break," indicating that the adsorption efficiency is constant over the length of the adsorber. The distribution curve for silver-copper ribbon breaks and changes slope at a depth of approximately 4 in. This effect could result from a different mechanism of adsorption becoming predominant at this depth and is thought to indicate that iodine vapor is the species being adsorbed at the entrance to the adsorber while the species giving rise to the break is due to iodine adsorbed on dust particles which are penetrating the adsorber. Efficient prefiltration of the air supply reduced this effect somewhat.

The application of charcoal for iodine adsorption may be limited somewhat by its tendency toward rapid oxidation at high temperatures in an oxidizing atmosphere (2). Heating of the charcoal can occur from both the beta decay of adsorbed radioiodine and the heat content of the gas containing the iodine vapor. For this reason, the use of charcoal in systems where the temperature is high $\left(>150^{\circ} \mathrm{C}\right)$ and oxidizing gases are present should be viewed cautiously, and some means of cooling the gas stream or charcoal applied. Silver-copper ribbon gains in efficiency when the temperature increases but reaches a maximum at $300^{\circ} \mathrm{C}$, and at higher temperatures the collected iodine is released. One factor to be noted is that once exposed to high temperatures the silver-copper ribbon is no longer effective at room temperature.

Silver-copper ribbon exhibits a sensitivity to iodine concentration in the air. At low concentrations $\left(10^{-3} \mathrm{mg} / \mathrm{ft}^{3}\right)$ the efficiency may drop to $90 \%$ as compared with 98 to $99 \%$ when the concentration is in the milligrams per cubic foot range. Charcoal has not exhibited this sensitivity and has a high efficiency over a wide concentration range. Earlier work at this Laboratory $(l)$ indicated that charcoal has an efficiency of $99.95 \%$ at concentrations of approximately $10^{-6} \mathrm{mg}$ of $\mathrm{I}^{131}$ per cubic foot of air. One test reported by workers at Harvard gave an efficiency of $96.8 \%$ for 8-14 mesh charcoal at an iodine concentration of approximately $4 \times 10^{-9} \mathrm{mg}$ of $\mathrm{I}^{131}$ per cubic foot of air.

It seems that the choice of using charcoal or silver-copper ribbon will depend mainly upon the decontamination efficiency desired in the air cleanup and upon the pressure drop that can be tolerated. On the basis of decontamination efficiency alone, 6-8 mesh charcoal is superior to the other adsorbents tested. In Fig. 6 the various mesh sizes of charcoal and silver-copper ribbon are compared, based upon decontamination factor as a function of depth of adsorbent. The multitude 


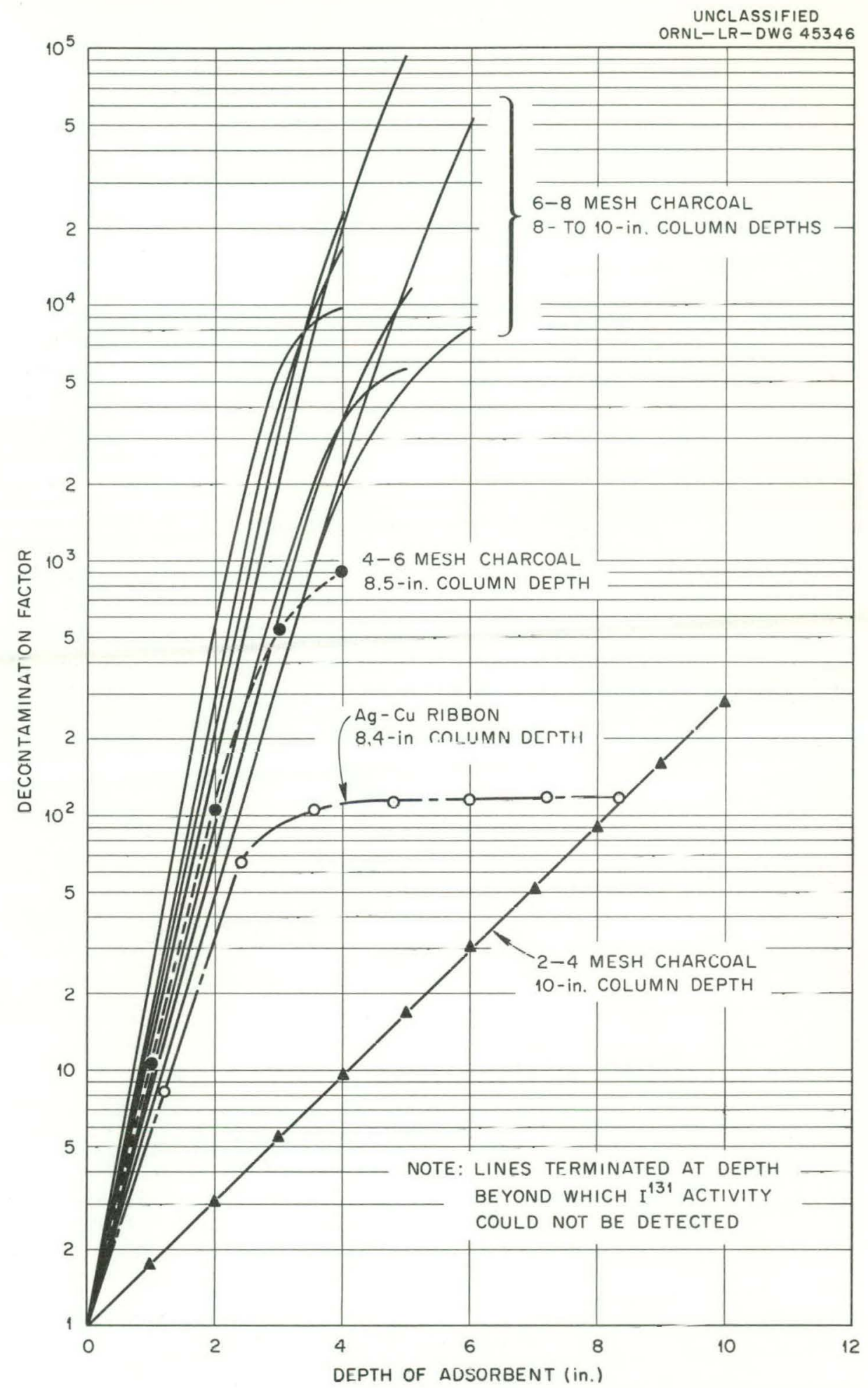

Fig. 6. Decontamination Factor as a Function of Adsorbent Depth. 
of lines for 6-8 mesh charcoal represents tests under the various conditions of superficial air velocity, moisture content, and duration of air sweep. The decontamination factor is defined as the amount of iodine found in the adsorber column divided by the amount of iodine which passed through. In an attempt to relate pressure drop, superficial air velocity, and decontamination efficiency, a plot was made of the decontamination factor as a function of pressure drop divided by superficial air velocity. This information is contained in Fig. 7. The curve for 6-8 mesh

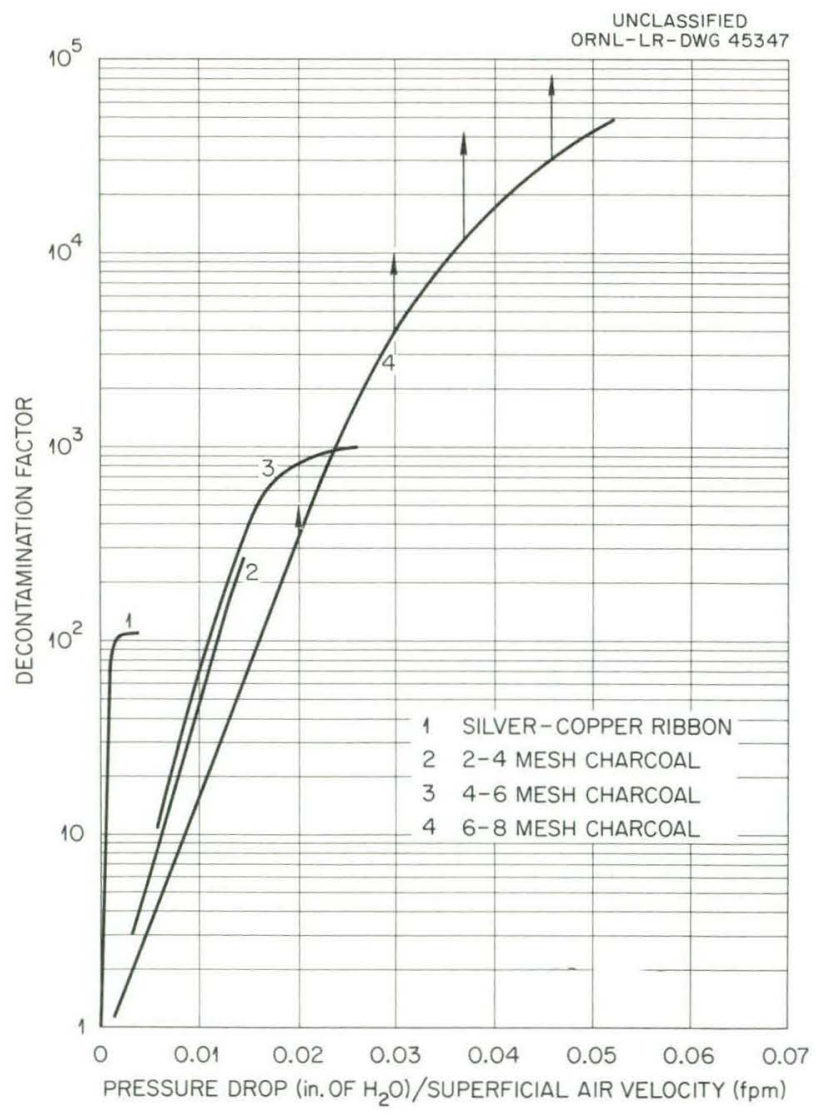

Fig. 7. Decontamination Factors as a Function of Pressure Drop and Superficial Air Velocity.

charcoal represents one interpretation for consolidating the data presented in Fig. 6 for this adsorbent. Although these curves are based on limited data, some tentative conclusions can be drawn regarding the relative merits of the silvercopper ribbon and several mesh sizes of charcoal for application at air velocities in the range 150 to $200 \mathrm{fpm}$. From the standpoint of pressure drop, silver-copper ribbon is superior to charcoal for decontamination factors up to 100 . Between decontamination factors of 100 to $300,2-4$ or 4-6 mesh is more suitable; from 300 to $1000,4-6$ is the choice; above $1000,6-8$ mesh is preferable.

\section{PRNC IODINE ADSORPTION SYSTEM}

The quantity of iodine likely to be released from a swimming pool reactor core through an accident and the resulting air concentration are speculative matters. Laboratory experiments on the release of iodine vapor from melted reactor fuel elements have shown that the quantity depends upon the fuel type and the identity of the atmosphere, among other variables (6). The amount of iodine that would actually reach the charcoal is also open to question, since iodine vapor would be expected to plate out on most exposed surfaces in the building, based upon reported results of iodine deposition and air diffusion experiments $(5,13)$. In addition, a large portion of the iodine will be retained in the particle filter. Experiments are reported which indicate that CWS-type filters will remove $90 \%$ or more of the radioiodine contained in moist air streams (10). Therefore, air concentration of iodine could vary over wide limits, and, for this reason, activated charcoal would be preferable to silver-plated copper ribbon since charcoal has a high efficiency over wide concentration ranges.

The pressure drop through a charcoal mass can be reduced by decreasing the depth of adsorbent and increasing the area exposed to air flow. This constitutes reducing the superficial velocity of air flow through the charcoal. A commercial canister which contains the charcoal between two concentric cylinders having perforated walls, thus increasing the exposed charcoal area, is shown in Fig. 8. Canisters of this type are available from the Charles E. Manning Company, Pittsburgh, Pennsylvania, and the Connor Engineering Corporation, Danbury, Connecticut. Several canisters, designated as type $\mathrm{H}-42$ and having a charcoal depth of 0.75 in., were purchased from the Connor Engineering Corporation and tested. Each canister, containing $1.5 \mathrm{lb}$ of 6-14 mesh charcoal, is rated to process air at a maximum of $25 \mathrm{cfm}$ and was tested for iodine vapor adsorption at that flow rate.

Three canisters were arranged in series, as shown in Fig. 9. The iodine vapor was injected 
UNCLASSIFIED

ORNL-LR-DWG 45348

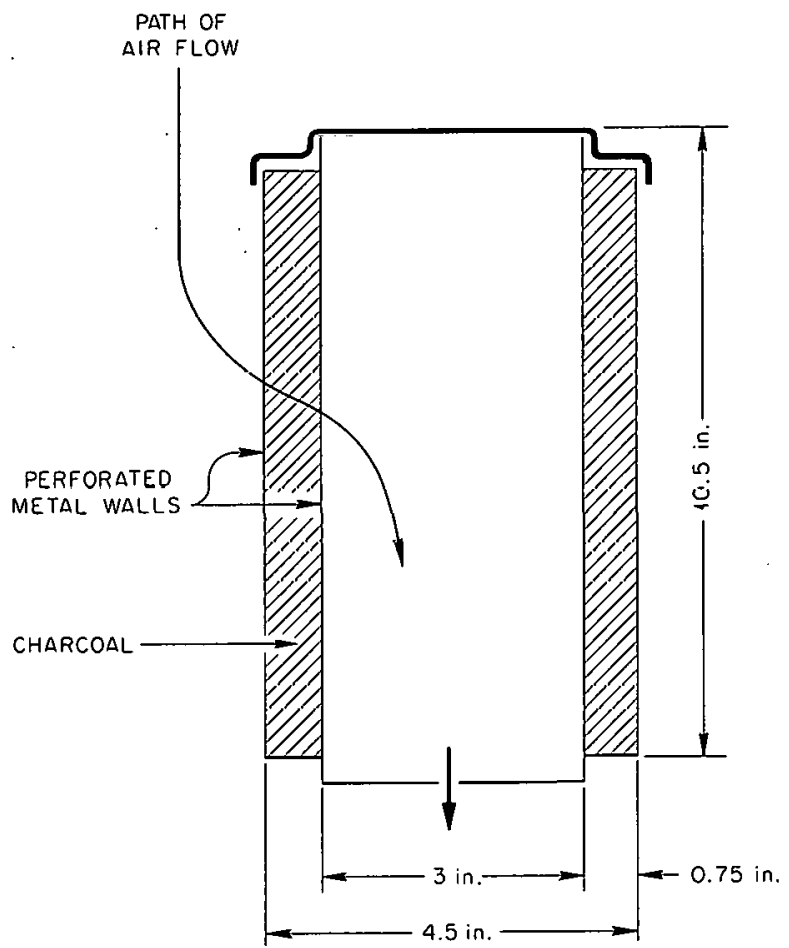

Fig. 8. Cruss Section of Activated Charcoal Canister.

for $40 \mathrm{~min}$, with an average concentration of 0.015 $\mathrm{mg}$ of $1^{127}$ and $4 \mu \mathrm{c}$ of $\mathrm{I}^{131}$ per cubic foot, and the air flow through the system was continued for $24 \mathrm{hr}$. Each canister has an exposed surface of $1 \mathrm{ft}^{2}$, and at a flow rate of $25 \mathrm{cfm}$, the superficial air velocity through the charcoal is $25 \mathrm{fpm}$. In addition to using the collector shown in Fig. 8, an attempt was made to detect iodine activity by monitoring a large volume of the exhaust air with a gamma-ray spectrometer, but the results were negative. The entire assembly was analyzed for $1^{131}$ after completion of the test. The three-stage system had an efficiency of $99.998 \%$, with the first, second, and third canisters exhibiting efficiencies of $99.99,74.6$, and $14.5 \%$, respectively.

A small portion of the iodine-containing charcoal from the first canister was placed in a section of l-in.-dia glass pipe, and air at a superficial velocity of $75 \mathrm{fpm}$ was passed through the charcoal in an effort to sweep out the iodine. The iodine activity in the system was monitored periodically by a gamma-ray spectrometer. After $250 \mathrm{hr}$ the activity was still decaying with a half life

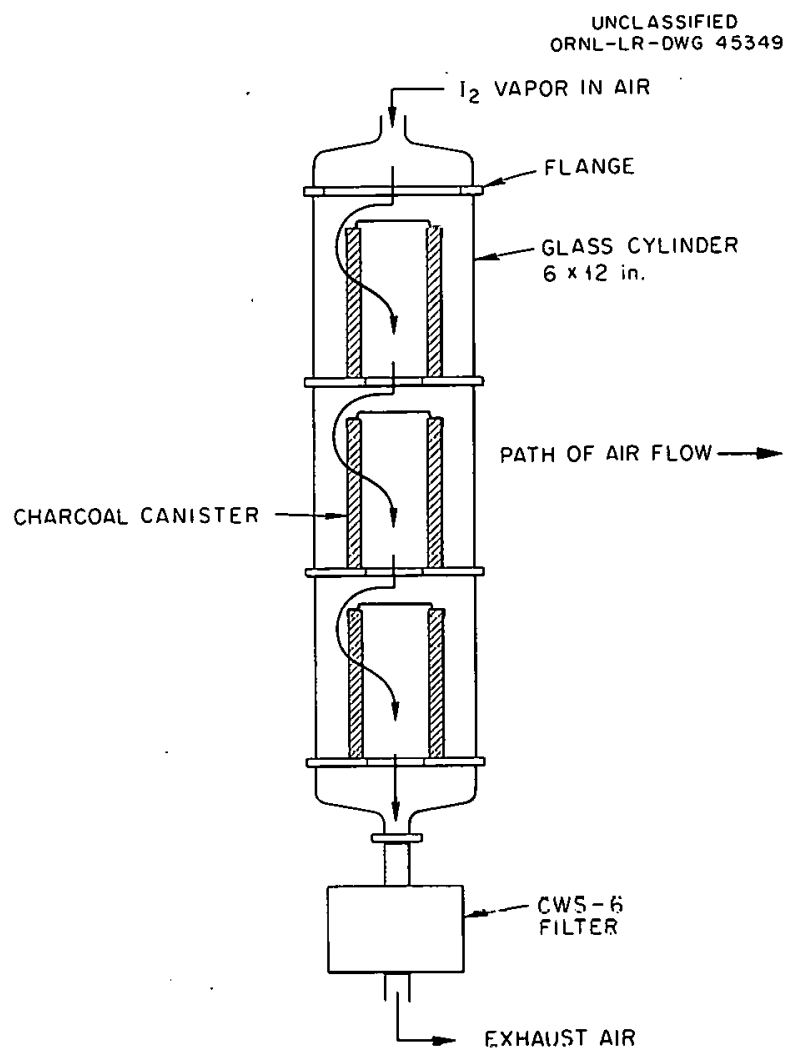

Fig. 9. Experımental System for Canister Test.

identical to that of $1^{131}(8.05$ days). This information, displayed in Fig. 10, supports the assumption that iodine is permanently adsorbed by the charcoal, or, in other words, reacts chemically with the charcoal surface and is not readily removed by continued air flow.

It is proposed that activated charcoal be used in the emergency exhaust system of the PRNC reactor building. Canisters, of the type tested in the laboratory, or equivalent, are suitable if one canister is used per $25 \mathrm{cfm}$ of exhaust air. A large number of canisters may be installed in parallel by utilizing a patented manifold mounting plate available from the manufacturer of the canisters. Pressure drop through one $\mathrm{H}-42$ canister at $25 \mathrm{cfm}$ is $0.15 \mathrm{in}$. of water, as quoted in the manufacturer's literature.

The problem of heating in the charcoal and consequent oxidation is not considered to be serious in this application since the heat released by a reactor accident will be dissipated in the pool water and the large volume of air in the 
building. The iodine would be adsorbed in a large number of canisters, and the local heating of

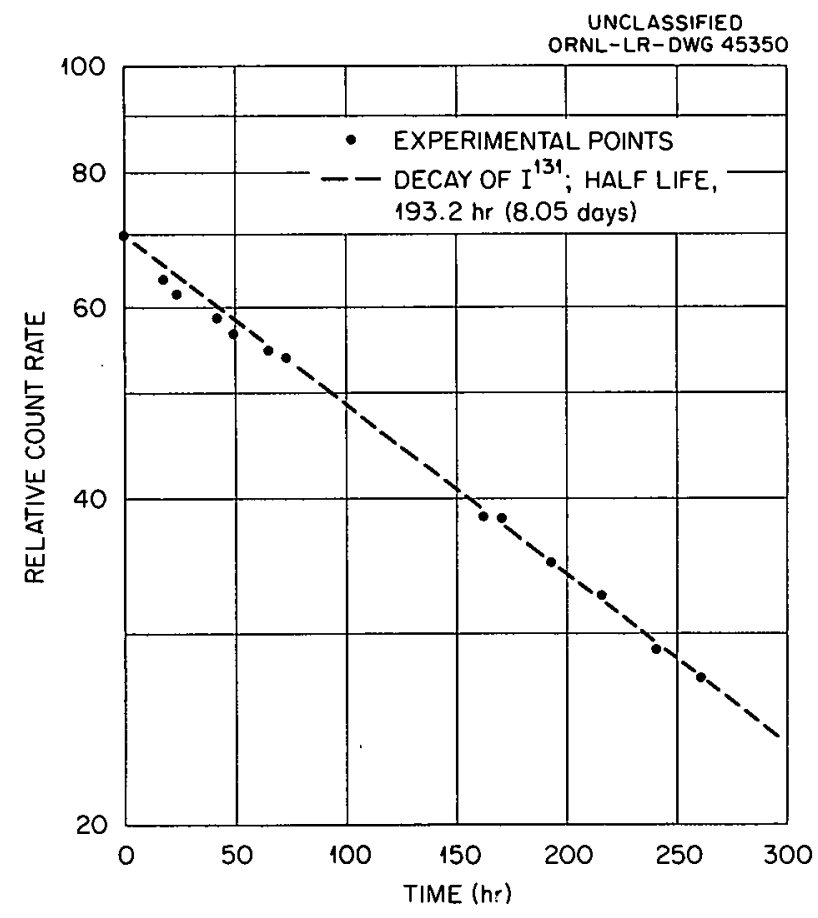

Fig. 10. Decay Rate of $1^{131}$ in a Dynamic System. the charcoal by beta decay would be minimized by the cooling effect of the exhausting air. Control of combustion, if it should occur, could be handled by diverting the air flow to an alternate charcoal system and allowing the affected canisters to burn out. A smouldering canister would not be expected to ignite adjacent canisters, and only a small fraction of iodine contained in the system would be released. This iodine would deposit at other points, and the release to the atmosphere would be almost nil. Experimental tests of the control of charcoal fires have been reported (2). In addition to the particle filter upstream from the charcoal, it is suggested that an additional filter be installed downstream from the charcoal to prevent the discharge into the atmosphere of fine, iodine-laden dust particles which may be released from the charcoal mass.

\section{ACKNOWLEDGMENTS}

The authors wish to acknowledge the assistance of H. T. Russell of the Isotopes Division in preparing the iodine tracer and the analytical services provided by R. R. Rickard of the Analytical Chemistry Division. 


\section{BIBLIOGRAPHY}

(1) R. E. Adams and W. E. Browning, Proposed Method for Removal of Radioiodine Vapor from Experiment Off-Gas System of the ORR, ORNL CF-58-5-59 (May 21, 1959).

(2) R. E. Adoms and W. E. Browning, Estimate of the Probability and Consequences of Ignition of the HRT Charcoal Beds, ORNL CF-58-6-6 (June 3, 1958).

(3) A. G. Blasewitz et al., Decontamination of Dissolver Vent Gases at Hanford, HW-20332 (Feb. 16, 1951).

(4) J. R. Bower and G. K. Cederberg, IDO-14419 (Sept. 25, 1957) (classified); IDO-14422 (Dec. 31, 1957) (classified); ICPP Tech. Prog. Rep. Sept. 1958, IDO-14457 (Feb. 2, 1959) (unclassified).

(5) A. C. Chamberlain, Experiments on the Deposition of lodine-131 Vapour onto Surfaces from an Airstream, AERE-HP/R-1082 (January 1953).

(6) G. E. Creek, W. J. Martin, and G. W. Parker, Experiments on the Release of Fission Products from Molten Reactor Fuels, ORNL.2616 (Dec. 23, 1958).

(7) J. W. Finnigan et al., Removal of lodine Vapor from Gas Streams by Sorption on Charcoal, $\mathrm{HW}-26113$ (Nov, 4, 1952),

(8) R. H. Flowers and B. F. Greenfield, The Removal of Bromine and lodine from the Helium Purge of an H.T.G.C. Reactor, AERE-C/M-354 (AugusI 1958).

(9) N. J. Keen and K. Alcock, The Reaction of Fission Product lodine with Solvents, AERE-C/M-186 (October 1953).

(10) A. S. Kester, Removal of Radioiodine from PWR Plant Container Air, WAPD-PWR-CP-2428 (Sept. 25, 1956); WAPD-PWR-CP-2673 (addendum).

(11) R. McNabney, Adsorption of Iodine Vapor, U.S. Patent 2,795,482 (to U.S. Atomic Energy Commission), June 11, 1957.

(12) R. McNabney and A. N. Lyon, The Removal of Iodine from Gas Streams by Reaction with Silver in Packed Towers, ARSC-28 (Aug. 26, 1948).

(13) H. J. de Nordwall and R. H. Flowers, The Diffusion of lodine in Air, AERE-C/M-342 (May 1958).

(14) D. M. Paige et al., Fifth AEC Air Cleaning Conference, June, 1957, TID-7551.

(15) L. Silverman et al., Paper presented at the Sixth AEC Air Cleaning Conference, Idaho Falls, Idaho, July 1959 (to be published).

(16) R. F. Taylor, "Absorption of lodine Vapor by Aqueous Solutions," Chem. Eng. Sci. 10, 68 (1959).

(17) M. A. Wahlgren and W. W. Meinke, "Molecular Sieves Adsorb lodine-131 from Air," Nucleonics 15(9), 156 (1957). 
THIS PAGE

\section{WAS INTENTIONALLY \\ LEFT BLANK}


1. A. A. Abbatiello

2. R. D. Ackley

3-27. R. E. Adams

28. S. E. Beall

29. R. L. Bennett

30. R. G. Berggren

31. D. S. Billington

32. F. T. Binford

33. G. E. Boyd

34. E. J. Breeding

35-59. W. E. Browning

60. F. R. Bruce

61. W. D. Burch

62. T. J. Burnett

63. C. D. Cagle

64. W. R. Casto

65. C. E. Center

66. R. A. Charpie

67. J. H. Clark

68. R. L. Clark

69. R. S. Cockreham

70-76. T. E. Cole

77. E. Collins

78. E. L. Compere

79. J. A. Conlin

80. W. B. Cottrell

81. J. A. Cox

82. J. H. Crawford

83. F. L. Culler

84. C. W. Cunningham

85. J. E. Cunningham

86. W. Dunlap

87. J. C. Ebersole

88. L. B. Emlet (K-25)

89. E. P. Epler

90. D. E. Ferguson

91. A. B. Fuller

92. P. A. Gnadt

93. W. R. Grimes

94. C. S. Harrill

95. H. L. Hemphill

96. A. S. Householder

97. G. H. Jenks

98. W. H. Jordan

99. S. I. Kaplan

100. G. W. Keilholtz

101. C. P. Keim

102. M. T. Kelley
103. H. V. Klaus

104. K. A. Krause

105. J. A. Lane

106. J. E. Lee, Jr.

107. R. E. Leuze

108. S. C. Lind

109. R. S. Livingston

110. R. A. Lorenz

111. H. G. MacPherson

112. F. C. Maienshein

113. W. L. Marshall

114. H. J. Metz

115. J. P. McBride.

116. F. H. McDuffie

117. R. E. McHenry

118. R. A. McNees

119. F. R. McQuilkin

120. J. R. McWherter

121. W. H. Montgomery

122. J. G. Morgan

123. K. Z. Morgan

124. J. P. Murray $(Y-12)$

125. F. H. Neill

126. M. L. Nelson

127. G. W. Parker

128. D. Phillips

129. W. T. Rainey

130. P. E. Reagan

131. P. M. Reyling

132. R. R. Rickard

133. A. F. Rupp

134. H. T. Russell

135. H. W. Savage

136. H. E. Seagren

137. R. L. Senn

138. R. P. Shields

139. E. D. Shipley

140. A. J. Shor

141. O. Sisman

142. M. J. Skinner

143. A. H. Snell

144. I. Spiewak

145. W. Stanley

146. R. W. Stoughton

147. J. A. Swartout

148. W. H. Tabor

149. E. H. Taylor

150. D. B. Trauger 
151. W. E. Unger

152. G. C. Williams

153. J. C. Wilson

154. R. Van Winkle

155. C. E. Winters

156. A. M. Weinberg

157. H. O. Weeren

158. J. W. Youngblood

159. E. J. Witkowski

160. J. Zasler
161. J. C. Zukas

162. Biology Library

163. Health Physics Library

164. Reactor Experimental

Engineering Library

165-166. Central Research Library

167-186. Laboratory Records Department

187. Laboratory Records, ORNL R.C.

188-189. Y-12 Technical Library,

Document Reference Section

\section{EXTERNAL DISTRIBUTION}

190. Division of Research and Development, AEC, Washington

191. Division of Research and Development, AEC, ORO

192. Oak Ridge Institute of Nuclear Studies

193. Division of Reactor Development, AEC, Washington

194. Division of Reactor Development, AEC, ORO

195. Plum Brook Reactor Facility, Sandusky, Ohio (F. Burns)

196. U.S. Naval Research Laboratory, Washington (J. O. Elliot)

197. Hanford Atomic Products Operation (E. L. Etheridge)

198. Brookhaven National Laboratory (P. R. Tichler)

199. Harvard University Air Cleaning Laboratory, Boston (L. Silverman)

200. Division of Raw Materials, AEC, Washington (R. D. Nininger)

201. Division of Raw Materials, AEC, Denver (D. L. Everhart)

202. Grand Junction Operations Office, AEC, Grand Junction, Colo. (Manager)

203. AEC, ORO (F. A. Gifford)

204-770. Given distribution as shown in TID-4500 (15th ed.) under Radioactive Waste category ( 75 copies - OTS) 